\title{
Last days in the old radiation laboratory (ORL), Berkeley, California, 1954
}

\author{
Andrew A. Benson
}

Received: 7 August 2010/ Accepted: 11 August 2010/Published online: 2 September 2010

(C) The Author(s) 2010. This article is published with open access at Springerlink.com

\begin{abstract}
Govindjee, the founding editor of the Historical Corner of Photosynthesis Research, invited me 3 years ago to tell the story of why I left Melvin Calvin's laboratory in the mid 1950s long before the 1961 Nobel Prize in Chemistry was awarded to Calvin for the path of carbon in photosynthesis. I have already written my scientific perspective on this topic (see Benson (Photosynth Res 73: 29-49, 2002); also see Bassham (Photosynth Res 76:35-52, 2003) as he was also a major player in this research). Here, I present my recollections of my last days in the old radiation laboratory (ORL) at Berkeley, California. References have been added by Govindjee for the benefit of the readers.
\end{abstract}

Keywords John Barltrop - Melvin Calvin · R. Clint Fuller - Jacques Mayaudon · J. Rodney Quayle · Thioctic (Lipoic) acid · Sam G. Wildman · Cornelis B. Van Niel

Beginning in 1952 and extending well into 1954, Melvin Calvin pursued an apparently brilliant idea that involved a chlorophyll-sensitized photochemical reaction of thioctic (lipoic) acid with water to yield a reducing "-SH" and an oxidizing "-SOH" group which could conceivably provide the reduced pyridine nucleotides and the hydroperoxides leading to oxygen in photosynthesis (see e.g., Barltrop

This special historical letter was invited and edited by Govindjee, Founding Editor of the Historical Corner of Photosynthesis Research. It was read and approved by Bob B. Buchanan of the University of California, Berkeley (See Guest Editorial by Govindjee).

\section{A. A. Benson ( $\square)$}

Scripps Institution of Oceanography, University of California at San Diego, 9500 Gilman Drive, La Jolla, CA 92093-0202, USA

e-mail: abenson@ucsd.edu; abcdeebenson@att.net et al. 1954; Calvin 1954). (For Calvin's biography, see Seaborg and Benson (1998).) Everyone in the laboratory was impressed and excited. In the first public presentation of the theory (American Association of the Advancement of Science (AAAS) Meeting, Berkeley, California, 1954), the world-renowned microbiologist Cornelis B.Van Niel, himself a pioneer in photosynthesis, was so impressed that he jumped from his front row seat to congratulate Calvin (see Benson 1995; Fuller1999).

Thioctic acid involvement in the photochemical aspects of the quantum conversion of photosynthesis had consumed at least 2 years of the laboratory's time and enthusiasm and that of John Barltrop, who was visiting from the Department of Chemistry of the University of Oxford in England (Barltrop et al. 1954; Calvin 1954).

The Laboratory's interest in sulfur metabolism engendered my experiment with the green alga Chlorella cultured with radioactive S-35 sulfate and chromatography of the products. A major (>99\%) S-35 labeled product appeared on the film in the location predicted for thioctic acid. Seeing this, Melvin's eyes almost fell onto the white tabletop. He urged Clint Fuller to search the area with a sensitive bioassay for thioctic acid (Fuller 1999). Melvin's interest heightened even further.

I had been involved in successful efforts with J. Rodney(Rod) Quayle and R. Clint Fuller in demonstrating the function of a carboxylase enzyme for $\mathrm{CO}_{2}$ uptake in algae and photosynthetic bacteria. My role was primarily in the preparation of unlabeled ribulose bisphosphate, the required "acceptor" for ${ }^{14} \mathrm{CO}_{2}$. It was essential for assay of the carboxylase enzyme. Melvin's efforts to substantiate his Thioctic Acid Theory prevented him from noticing my feverish efforts with a Belgian scientist, Jacques Mayaudon. Calvin seemed totally disinterested in my work. Thus, in the fall of 1954, I was not telling him what Jacques and I were 
doing: though it was much like my work with Rod Quayle and Clint Fuller (Quayale et al. 1954).

It was then (December 10,1954) that Melvin told me, "It is time to go." (It was obvious that it meant I had to leave the laboratory.) I had no place to go, and he made no apparent effort on my behalf. After playing a major role in deciphering the pathway, I was dismissed. With Al Bassham and others in the laboratory, we had been very successful and published our 21st article, in 1954, on the path of carbon in photosynthesis (see Bassham et al. 1954; also see Appendix). I had played a major role in identifying the intermediates in the Path of Carbon in Photosynthesis and was responsible for the discovery of ribulose 1,5-bisphosphate-the "missing" intermediate that was central to formulating the final cycle. It is unfortunate that Calvin appended the thioctic acid hypothesis in this 1954 article. The idea was soon dead as Fuller's analyses gave no evidence for the participation of thioctic acid.

Neither Jacques nor Melvin was familiar with the recognition and isolation of "Fraction-1 Protein" by Sam Wildman (see Wildman 2002). I had visited Sam in his office and laboratory at Caltech frequently during that time. Sam explained to me the universal occurrence of a major fraction of proteins, Fraction 1 protein, in plant leaves and its purification by precipitation at $35 \%$ with increasing concentrations of saturated ammonium sulfate solution. Jacques's saturated ammonium sulfate precipitations indicated that the carboxylase enzyme separated at $35 \%$, the same as Wildman's Fraction 1 Protein. We had discovered that the carboxylase and Fraction-1 Protein are identical. I phoned Sam Wildman with the news and typed a two-page report that I felt obliged to submit to Melvin as I departed. The fate of this article is another story (see below).

Melvin had no concept of the importance of the identity of Fraction-1 Protein and carboxydismutase (now called ribulose 1,5-bisphosphate carboxylase or Rubisco). After I departed, Melvin directed Rod Quayle's and Jacques Mayaudon's efforts. They were clearly not pointed toward proving the identity of carboxydismutase and the Fraction-1 Protein, but more toward documenting the physical properties of the carboxylating enzyme. Jacques and Rod were not in a position to complain since they had not read Wildman and Bonner's article on Fraction 1 Protein (Wildman and Bonner 1947) and many others (see Wildman 1998). In the end, the Enzymologia article by Mayaudon was published without my knowledge and without consulting Jacques (Mayaudon 1957). He wrote to me that he was unaware of its transmission although he was the sole author.

Publication of "Following the Trail of Light," a 1992 autobiography by Melvin Calvin, replete with photos and description of the Nobel Prize ceremony, made no reference of my work or publications (Calvin 1992). Melvin's 93 publications are listed, whereas 32 publications by

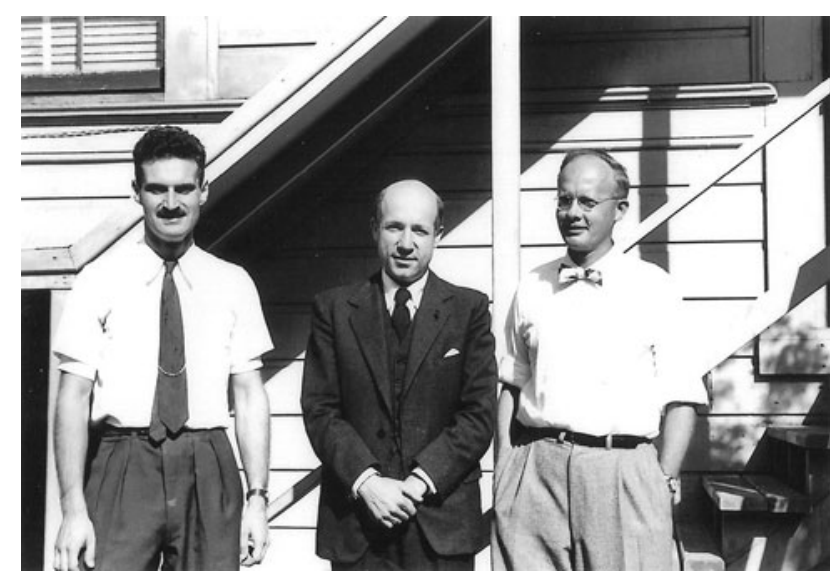

Fig. 1 Left to right Jacques Mayaudon, Melvin Calvin, and Andrew A. Benson (the author). Photo taken in 1954, University of California, Berkeley, California. Photo by Paul M. Hayes

Benson and Calvin are not listed (see Bassham et al. 1950; Benson 2002; and Appendix given below for a list of some of the papers from that time, arranged chronologically; see specifically 1950, 1951 and 1952 listings). Melvin even included a photo of himself and 12 people involved in the laboratory, entitled "My Staff" and failed to mention the fact that I had taken the picture. In the Nobel lecture delivered on December 11, 1961, Calvin (1964), however, did cite one article, Calvin and Benson (1948), among a total of 30 articles and reviews.

I end this historical personal account by showing a photograph of myself with Jacques Mayaudon and Melvin Calvin, taken in 1954 (Fig. 1).

Govindjee, this is my story and I hope that it answers your question (see Abstract).

Acknowledgments I thank Dee Benson and Carole Mayo for their valuable help in getting this manuscript completed in its present form. This manuscript was read and approved by Bob B. Buchanan, of University of California, at Berkeley; I thank him for his encouragement and support to publish this story. The person who deserves the most credit is Govindjee for his unwavering persistence, regular telephone calls, reminders, and his editorial and friendly advice over the years that allowed this story to be told to the photosynthesis community. Finally, his help with the references is greatly appreciated.

Open Access This article is distributed under the terms of the Creative Commons Attribution Noncommercial License which permits any noncommercial use, distribution, and reproduction in any medium, provided the original author(s) and source are credited.

\section{Appendix}

A partial list of published articles by Benson et al. (1947-1956), prepared by Govindjee.

\section{7}

Benson AA and Calvin M (1947) The dark reductions of photosynthesis. Science 105: 648-649. 
Aronoff S, Benson A, Hassid WZ and Calvin M (1947) Distribution of $\mathrm{C} 14$ in photosynthesizing barley seedlings. Science 105: 664-665.

\section{8}

Calvin M and Benson M (1948) The path of carbon in photosynthesis. Science 107: 476-480.

Stepka W, Benson AA and Calvin M (1948) The path of carbon in photosynthesis.II. Science 108: 304.

Benson AA and Calvin M (1948) The path of carbon in photosynthesis. III. Cold Spring Harbor Symposia in Quantitative Biology 13: 6-10.

Benson AA and Bassham JA (1948) Chemical degradation of isotopic succinic and malic acids. J Am Chem Soc 70: 3939.

\section{9}

Calvin M and Benson AA (1949) The path of carbon in photosynthesis.IV. Science 109: 140-142.

\section{0}

Benson AA and Calvin M (1950a) Carbon dioxide fixation by green plants. Annu Rev Plant Physiol 1: 25-42.

Benson AA and Calvin M (1950b) The path of carbon in photosynthesis.VII. Respiration and Photosynthesis. J Exper Bot 1 : 63-68.

Benson AA, Bassham JA, Calvin M, Goodale TC, Haas VA and Stepka W (1950) The path of carbon in photosynthesis.V.Paper chromatography and radioautography of the products. J Am Chem Soc 72: 1710-1718.

Bassham JA, Benson AA and Calvin M (1950) The path of carbon in photosynthesis.VIII. Role of Malic acid. J Biol Chem 185: 781-787.

Calvin M, Bassham JA and Benson AA (1950) Chemical transformation of carbon in photosynthesis. Fed Proc 9 : $524-534$

\section{1}

Benson AA (1951a) The sequence of formation of hexoses during photosynthesis. Arch Biochem Biophys 32: 223-224.

Benson AA (1951b) Identification of ribulose in $\mathrm{C}^{14} \mathrm{O}_{2}$ photosynthetic products. J Am Chem Soc 73: 2971.

Benson AA, Bassham JA and Calvin M (1951) Sedoheptulose in photosynthesis by plants. J Am Chem Soc 73: 2970.

\section{2}

Ouellet C and Benson AA (1952) The path of carbon in photosynthesis.XIII. pH effects in $\mathrm{C}^{14} \mathrm{O}_{2}$ fixation by Scenedesmus. J Exper Bot 3: 237-245.
Benson AA, Bassham JA Calvin M, Hall AG, Hirsch HE, Kawaguchi S, Lynch V and Tolbert NE (1952a) The path of carbon in photosynthesis.XV. Ribulose and Sedoheptulose.. J Biol Chem 196: 703-716.

Benson AA, Kawaguchi S, Hayes P and Calvin M (1952b) The path of carbon in photosynthesis.XVI. Kinetic relationships of the intermediates in steady state photosynthesis. J Am Chem Soc 74: 4477-4482.

Calvin M, Bassham JA, Benson AA and Massini P (1952) Photosynthesis. Annu Rev Phys Chem 3 : 215-228.

Benson AA (1952) Mechanism of biochemical photosynthesis. Zeit Elektrochemie 56: 848-854.

\section{3}

Bassham JA, Benson AA and Calvin M (1953) Isotope studies in photosynthesis. J Chem Educ 30: 274-283.

Buchanan JG, Lynch VH, Benson AA, Bradley DF and Calvin M (1953) The path of carbon in photosynthesis.XVIII. The identification of nucleotide coenzyme. J Biol Chem 203: 935-945.

\section{4}

Bassham JA, Benson AA, Kay LD, Harris AZ, Wilson AT and Calvin M (1954). The path of carbon in photosynthesis. XXI. The cyclic regeneration of carbon dioxide acceptor. J Am Chem Soc 76: 1760-1770.

Benson AA (1954) Photosynthesis: First reactions. J Chem Educ 31: 484-487.

Quayale JR, Fuller RC, Benson AA and Calvin M (1954). Enzymatic carboxylation of ribulose diphosphate photosynthesis.. J Am Chem Soc 76: 3610- 3611.

Shibata K, Benson AA and Calvin M (1954) The absorption spectra of suspensions of living microorganisms. Biochim Biophys Acta 15: 461-470.

Nordal A and Benson AA (1954) Isolation of mannoheptulose and identification of its phosphate in avocado leaves. J Amer Chem Soc 77: 4257-4261.

\section{5}

Goodman M, Benson AA and Calvin M (1955) Fractionation of phosphates from Scenedesmus by anion exchange. J Amer Chem Soc 77: 4257-4261.

\section{6}

Milhaud G, Benson AA and Calvin M (1956) Metabolism of pyruvic acid-2-C $\mathrm{C}^{14}$ and hydroxypyruvic acid-2- $\mathrm{C}^{14}$ in algae. J Biol Chem 218: 599-606.

Nordal A, Benson AA and Calvin M (1956) Photosynthesis of sedoheptulose- $\mathrm{C}^{14}$. Arch Biochem Biophys 62: 435-445. 
Mayaudon J, Benson AA and Calvin M (1956) Ribulose-1,5 diphosphate from and $\mathrm{CO}_{2}$ fixation by Tetragonia expansa leaves extract. Biochim Biophys Acta 23: $342-351$.

\section{References}

Barltrop A, Hayes PM, Calvin M (1954) The chemistry of 1, 2dithiolane (trimethylene disulfide) as a model for the primary quantum conversion act in photosynthesis. J Am Chem Soc 76:4348-4367

Bassham JA (2003) Mapping the carbon reduction cycle: a personal retrospective. Photosynth Res 76:35-52

Bassham J, Benson A, Calvin M (1950) The path of carbon in photosynthesis. J Biol Chem 185(2):781-787

Bassham JA, Benson AA, Kay LD, Harris AZ, Wilson AT, Calvin M (1954) The path of carbon in photosynthesis XXI. The cyclic regeneration of carbon dioxide acceptor. J Am Chem Soc 76:1760-1770

Benson AA (1995) Saga of a great theory of photosynthesis. ASPB (American Society of Plant Biology) News Lett 22(6):5-6

Benson AA (2002) Following the path of carbon in photosynthesis: a personal story. Photosynth Res 73:29-49

Calvin M (1954) Chemical and photochemical reactions of thioctic acid and related disulfides. Fed Proc 13:697-711
Calvin M (1964) The path of carbon in photosynthesis. The Nobel Lecture, delivered on December 11, 1961, From Nobel Lectures, Chemistry 1942-1962. Elsevier Publishing Company, Amsterdam, pp 618-644

Calvin M (1992) Following the trail of light: a scientific odyssey. In: Seemen JE (ed) Profiles, pathways, and dreams. American Chemical Society, Washington, DC, pp 3-178

Calvin M, Benson M (1948) The path of carbon in photosynthesis. Science 107:476-480

Fuller RC (1999) Forty years of microbial photosynthesis research: where it came from and what it led to. Photosynth Res 62:1-29

Mayaudon J (1957) Study of association between the main nucleoprotein of green leaves and carboxydismutase. Enzymologia 18:345-354

Quayale JR, Fuller RC, Benson AA, Calvin M (1954) Enzymatic carboxylation of ribulose diphosphate photosynthesis. J Am Chem Soc 76:3610-3611

Seaborg GT, Benson AA (1998) Melvin Calvin (April 8, 1911January 1997). In: Biographical Memoirs, vol 75. National Academy of Sciences, Washington, DC, pp 96-115

Wildman SG (1998) Discovery of Rubisco. In: Kung S-D, Yang S-F (eds) Discoveries in plant biology, chap 12. World Scientific Pub. Co, Singapore, pp 163-173

Wildman SG (2002) Along the trail from fraction I protein to Rubisco (ribulose bis phosphate carboxylase-oxygenase). Photosynth Res 73:243-250

Wildman SG, Bonner J (1947) The proteins of green leaves. I. Isolation and enzymatic properties and auxin content of spinach cytoplasmic proteins. Arch Biochem 14:381-413 